\title{
Antioxidant, Anti-inflammatory and Cytotoxicity of Phaleria macrocarpa (Boerl.) Scheff Fruit
}

\author{
Rudi Hendra ${ }^{1,2 \dagger}$, Syahida Ahmad ${ }^{1 * \dagger}$, Ehsan Oskoueian ${ }^{3,5 \dagger}$, Aspollah Sukari ${ }^{4 \dagger}$ and M Yunus Shukor ${ }^{1 \dagger}$
}

\begin{abstract}
Background: Phaleria macrocarpa (Scheff.) Boerl (Thymelaceae) originates from Papua Island, Indonesia and grows in tropical areas. The different parts of the fruit of $P$. macrocarpa were evaluated for antioxidant, anti-inflammatory, and cytotoxic activities.

Methods: Phaleria macrocarpa fruit were divided into pericarp, mesocarp and seed. All parts of the fruit were reflux extracted with methanol. The antioxidant activity of the extracts were characterized in various in vitro model systems such as FTC, TBA, DPPH radical, reducing power and NO radical. Anti-inflammatory assays were done by using NO production by macrophage RAW 264.7 cell lines induced by LPS/IFN- $\gamma$ and cytotoxic activities were determined by using several cancer cell lines and one normal cell line

Results: The results showed that different parts (pericarp, mesocarp, and seed) of Phaleria macrocarpa fruit contain various amount of total phenolic $(59.2 \pm 0.04,60.5 \pm 0.17,47.7 \pm 1.04 \mathrm{mg}$ gallic acid equivalent/g DW) and flavonoid compounds ( $161.3 \pm 1.58,131.7 \pm 1.66,35.9 \pm 2.47 \mathrm{mg}$ rutin equivalent/g DW). Pericarp and mesocarp showed high antioxidant activities by using DPPH $(71.97 \%, 62.41 \%)$, ferric reducing antioxidant power $(92.35 \%, 78.78 \%)$ and $\mathrm{NO}$ scavenging activity $(65.68 \%, 53.45 \%)$. Ferric thiocyanate and thiobarbituric acid tests showed appreciable antioxidant activity in the percentage hydroperoxides inhibitory activity from pericarp and mesocarp in the last day of the assay. Similarly, the pericarp and mesocarp inhibited inducible nitric oxide synthesis with values of $63.4 \pm 1.4 \%$ and $69.5 \pm$ $1.4 \%$ in macrophage RAW 264.7 cell lines induced by LPS/IFN- $\gamma$ indicating their notable anti-inflammatory potential. Cytotoxic activities against HT-29, MCF-7, HeLa and Chang cell lines were observed in all parts.
\end{abstract}

Conclusions: These results indicated the possible application of $P$. macrocarpa fruit as a source of bioactive compounds, potent as an antioxidant, anti inflammatory and cytotoxic agents.

Keywords: Phaleria macrocarpa, antioxidant, anti-inflammatory, cytotoxic activity

\section{Background}

Text for this section. Ethnopharmacological information revealed the utilization of Phaleria macrocarpa (Scheff.) for many purposes by humans. The main purpose of plants was as a source of food and food additive however the plant is also used as a natural source of medicinal agents [1]. In recent years, research on medicinal plants has drawn enormous global attention. Large bodies of evidence have accumulated to demonstrate the promising potential of medicinal plants used in various traditional,

\footnotetext{
* Correspondence: syahida@biotech.upm.edu.my

+ Contributed equally

'Department of Biochemistry, Faculty of Biotechnology and Biomolecular Sciences, Universiti Putra Malaysia (UPM), 43400 UPM Serdang, Selangor, Malaysia

Full list of author information is available at the end of the article
}

complementary and alternate systems of treatment of human diseases. The plants are rich in a wide variety of secondary metabolites such as tannins, terpenoids, alkaloids, flavonoids, etc., which have been screened in vitro and indicated antioxidant, anti-inflammatory and antimicrobial properties are used to developed drugs or dietary supplements [2].

In Indonesia, most of the research activities in natural products are still limited to the inventory of folkloric information and utilization of various plants and trees, meaning that obtaining scientific proof for their biological activities are still challenging and need more investigation [3].

Phaleria macrocarpa (Scheff.) Boerl (Thymelaceae) is commonly known as crown of god, mahkota dewa, and pau. It originated from Papua Island, Indonesia and it

\section{Biomed Central}


grows in tropical areas. This plant is one the of most popular medicinal plants in Indonesia. Phaleria macrocarpa grows throughout the year in tropical areas reaching a height of around 1-6 m. It is a complete tree (stem, leaves, flower and fruit) and the fruit shape is eclipse with a diameter of around $3 \mathrm{~cm}$. The colour of the fruit is green before ripening and red when fully ripe [4]. Traditionally, P. macrocarpa (Scheff) Boerl has been used to control cancer, impotency, hemorrhoids, diabetes mellitus, allergies, liver and hearth disease, kidney disorders, blood diseases, acne, stroke, migraine, and various skin diseases [5].

Based on the ethopharmacological aspects the boiled water extract of the Phaleria macrocarpa fruit used to treat or alleviate the above diseases symptoms. Despite the extensive use by Indonesian people, there have been only limited attempts to explore the biological properties of this plant in relation to their medicinal uses. In our investigation into biological activities of Indonesian plants, we report here the total phenolic and flavonoid compounds, antioxidant, anti-inflammatory, cytotoxicity activities of the extracts from different parts of $P$. macrocarpa fruit.

\section{Methods}

\section{Plant Materials}

The fruits of Phaleria macorcarpa (Boerl.) Schiff. were obtained from Faculty of Mathematic and Natural Sciences, University of Riau, Riau province, Indonesia $\left(0^{\circ} 28^{\prime} 42.14 " \mathrm{~N}, 101^{\circ} 22^{\prime} 38.37^{\prime \prime} \mathrm{E}\right)$. The plant species was identified by the laboratory of Plant Taxonomy staff at Herbarium Bogoriense, Bogor, Indonesia. The voucher specimen (SA1611/2008) was deposited at Herbarium Bogoriense, Bogor, Indonesia. The fruit were washed and separated into pericarp, mesocarp and seed. Those parts were airdried for 7 days and kept for further analyses.

\section{Extract Preparation}

The extractions from various parts of $P$. macrocarpa fruit were carried out based on Crozier et al., [6] with some modification. Briefly, air-dried powders of each parts of $P$. macrocarpa fruit $(0.5 \mathrm{~g})$ were weighed and placed into a $100 \mathrm{ml}$ conical flask. $40 \mathrm{ml}$ of methanol was added, followed by $10 \mathrm{ml}$ and $6 \mathrm{M} \mathrm{HCL}$ solution. The mixture was stirred with a magnetic stirrer. The mixture was then placed in a sample flask $(250 \mathrm{ml})$, attached to reflux and heated for 2 hours at $90^{\circ} \mathrm{C}$, then filtered with a Whatman No.1 filter paper (Whatman, England). Filtrates were dried by using a vacuumed Rotary Evaporator (Buchii, Switzerland) at $40^{\circ} \mathrm{C}$.

\section{Total Phenolics Assay}

Total phenolic compounds were determined according to Ismail et al. [7]. $0.5 \mathrm{ml}$ of each extract, $2.5 \mathrm{ml}$ FolinCiocalteu reagent, $2 \mathrm{ml}$ of $7.5 \%(\mathrm{w} / \mathrm{v}) \mathrm{Na}_{2} \mathrm{CO}_{3}$ were mixed. The mixture was vortex and incubated at room temperature for $90 \mathrm{~min}$. The absorbances were read using a visible spectrophotometer (Novaspec II Visiblespectro) at $765 \mathrm{~nm}$. The results were expressed as $\mathrm{mg}$ gallic acid equivalents/g dry weight (DW).

\section{Total Flavonoid Assay}

The total flavonoid compounds in each extract was determined according to Ismail et al [7]. An aliquot $(0.1 \mathrm{ml})$ of extract was added to $0.3 \mathrm{ml} 5 \%(\mathrm{w} / \mathrm{v}) \mathrm{NaNO}_{2}$ and incu-

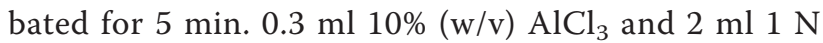
$\mathrm{NaOH}$ was added and the total volume was made up to $5 \mathrm{ml}$ with distilled water. The absorbance was measured at $510 \mathrm{~nm}$ by using visible spectrophotometer (Novaspec II Visiblespectro) at $510 \mathrm{~nm}$. The results were expressed as mg rutin equivalents/g DW.

\section{Antioxidant Activity of P. macrocarpa Extracts Total Antioxidant Activity Assay}

Ferric Thiocyanate (FTC) This assay was carried out as described in the modified method of Gülçin [8]. A mixture of $1.2 \mathrm{mg}$ of a sample in $4 \mathrm{ml}$ of $99.5 \%$ ethanol $(300 \mu \mathrm{g} /$ $\mathrm{ml}$ ), $4.1 \mathrm{ml}$ of $2.5 \%$ linoleic acid in $99.5 \%$ ethanol, $8.0 \mathrm{ml}$ of $0.02 \mathrm{M}$ phosphate buffer ( $\mathrm{pH} 7.0$ ) and $3.9 \mathrm{ml}$ of water contained in a screw-cap vial was placed in an oven at $40^{\circ} \mathrm{C}$ in the dark. To $0.1 \mathrm{ml}$ of this mixture, $9.7 \mathrm{ml}$ of $75 \%(\mathrm{v} / \mathrm{v})$ ethanol and $0.1 \mathrm{ml}$ of $30 \%$ ammonium thiocyanate was added. Three minutes after the addition of $0.1 \mathrm{ml}$ of $2.0 \times$ $10^{2} \mathrm{M}$ ferrous chloride in $3.5 \%$ hydrochloric acid to the reaction mixture, the absorbance was measured at $500 \mathrm{~nm}$ (Molecular Devices Inc., USA) at every 24 hour interval until 1 day after absorbance of the control reached its maximum value.

Thiobarbituric Acid (TBA) This test was conducted according to the method of Gülçin [8]. The same samples prepared for FTC method were used. To $2.0 \mathrm{ml}$ of the sample solution, was added $1.0 \mathrm{ml}$ of $20 \%$ aq. trichloroacetic acid and $2.0 \mathrm{ml}$ of aq. thiobarbituric acid solution. The final sample concentration was $0.02 \% \mathrm{w} / \mathrm{v}$. The mixture was placed in a boiling water bath for 10 minutes. After cooling, it was centrifuged at $3000 \mathrm{rpm}$ for 20 minutes. Absorbance of the supernatant was measured at $532 \mathrm{~nm}$ (Molecular Devices Inc., USA). Antioxidant activity was recorded based on absorbance on the final day. In both methods, antioxidant activity is described by percent inhibition: $\left[\left(A_{0}-A_{1}\right) / A_{0}\right] \times 100 \%$; where $A_{0}$ was the absorbance of the control reaction and $A_{1}$ was the absorbance in the presence of the sample.

DPPH Radical Scavenging Activity The free radical scavenging activity of the plant materials was determined using the DPPH assay as described by Gülçin. Briefly, One ml methanolic extract of each of plant at different concentration were mixed with $3 \mathrm{ml} 0.1 \mathrm{mM}$ solution of 2,2-diphenyl-1-picrylhydrazil (DPPH) in methanol. After incubation at room temperature for 
$30 \mathrm{~min}$ in the dark condition, the absorbance of the mixture was read using a visible spectrophotometer (Novaspec II Visblespectro) at $517 \mathrm{~nm}$. Ascorbic acid and $\alpha$-tocopherol were used as a antioxidant standard. Free radical scavenging activity from the sample was calculated according to the formula:

$$
\left[\left(A_{0}-A_{1}\right) / A_{0}\right] \times 100 \%
$$

where $A_{0}$ was the absorbance of the control reaction and $A_{1}$ was the absorbance in the presence of the sample.

Ferric-Reducing Antioxidant Power (FRAP) Assay The ferric reducing property of the extracts was determined by using assay described by Yen and Chen [9]. One ml (concentration of 100, 150, 200, 250, and $300 \mu \mathrm{g} / \mathrm{ml}$ ) of sample extracts were mixed with $2.5 \mathrm{ml}$ of potassium phosphate buffer $(0.2 \mathrm{M}, \mathrm{pH} 6.6)$ and $2.5 \mathrm{ml}$ of potassium ferricyanide $(1 \mathrm{~g} / 100 \mathrm{ml})$. The mixture was incubated at $50^{\circ} \mathrm{C}$ for $20 \mathrm{~min}$. Trichloroacetic acid (10\%) was added to the mixture to stop the reaction. Equal volume of distilled water was added followed by $0.5 \mathrm{ml}$ ferum chlorate $(0.1 \mathrm{~g} / 100 \mathrm{ml})\left(\mathrm{FeCl}_{3}\right)$. The procedure was carried out in triplicate and allowed to stand for $30 \mathrm{~min}$ before measuring the absorbance at $700 \mathrm{~nm}$. The above procedures were repeated with BHT, ascorbic acid and $\alpha$-tocopherol as positive control. The percentage of antioxidant activity in FRAP assay of the samples was calculated according to the formula:

$$
\text { Antioxidant Activity }(\%)=\frac{\left(\mathrm{A}_{1} \mathrm{~A}_{0}\right)}{\mathrm{A}_{1}}
$$

$\mathrm{A}_{0}=$ Absorbance of the control (potassium phosphate buffer + FRAP reagent)

$\mathrm{A}_{1}=$ Absorbance of sample

NO-Scavenging Activity The NO-scavenging activity of each plant extract was determined by the method of Tsai et al., [10]. Sixty microliters of two-fold dilution sample were mixed with $60 \mu \mathrm{l}$ of $10 \mathrm{mM}$ sodium nitroprusside in phosphate buffered saline (PBS) into a 96-wll flat-bottomed plate and incubated under light at room temperature for $150 \mathrm{~min}$. Finally, an equal volume of Griess reagent was added into each well in order to measure the nitrite content. Ascorbic acid and $\alpha$-tocopherol were used as a control. The NO-scavenging activity was calculated according to the formula: $\left[\left(A_{0}-A_{1}\right) / A_{0}\right] \times 100 \%$; where $A_{0}$ was the absorbance of the control reaction and $A_{1}$ was the absorbance in the presence of the sample.

Anti-inflammatory activity The murine monocytic macrophage RAW 264.7 cell line (European Cell Culture Collection, CAMR, UK) was cultured in Dulbecco's Modified Eagle Media (DMEM) (2 mM L-glutamine, $45 \mathrm{~g} / \mathrm{L}$ glucose, $1 \mathrm{mM}$ sodium pyruvate) with $10 \%$ fetal bovine serum (FBS). The cells were cultured at $37^{\circ} \mathrm{C}$ with $5 \%$
$\mathrm{CO}_{2}$ and were subcultured twice a week. The cells were seeded in 96-well tissue culture plates $\left(1 \times 10^{6}\right.$ cells $\left./ \mathrm{ml}\right)$ and incubated for $24 \mathrm{~h}$ at $37^{\circ} \mathrm{C}$ with $5 \% \mathrm{CO}_{2}$. Then, $100 \mu \mathrm{l}$ of test extract in DMSO was then added and serially diluted to give a final concentration of $200 \mu \mathrm{g} / \mathrm{ml}$ in $0.1 \%$ DMSO. Cells were then stimulated with $200 \mathrm{U} / \mathrm{ml}$ of recombinant mouse interferon-gamma (IFN- $\gamma$ ) and $10 \mu \mathrm{g} / \mathrm{ml}$ Escherichia coli lipopolysaccharide (LPS) and incubated at $37^{\circ} \mathrm{C}$ for another $17 \mathrm{~h}$. The presence of nitrite was determined in cell culture medium by Griess reagent and cell viability was detected by using MTT cytotoxicity assay as described by Ahmad et al. [11]. Nnitro-1-arginine-methyl ester (L-NAME) was used as iNOS inhibitor (control) at a concentration of $250 \mu \mathrm{M}$.

Cytotoxic Activity HT-29 (Human colon adenocarcinoma cell line), MCF7 (Human breast adenocarcinoma cell line), HeLa (Human cervical cancer cell line), Human hepatocytes (Chang liver cells) and obtained from the American Type Culture Collection (ATCC) were used in this study.

Cytotoxicity was determined using the 3-(4,5dimethylthiazol-2-yl)-2,5-diphenyltetrazolium bromide (MTT, Sigma) assay reported by Mosmann [12]. The plant extracts were prepared from the stock solutions by serial dilution in DMEM to give a volume of $100 \mu \mathrm{l}$ in each well of a microtiter plate (96-well). Each well was filled with $100 \mu \mathrm{l}$ of cells at $2 \times 10^{5}$ cells $/ \mathrm{ml}$. The assay for each concentration of extract was performed in triplicates and the culture plates were kept at $37^{\circ} \mathrm{C}$ with $5 \%$ (v/v) $\mathrm{CO}_{2}$ for 3 days. After $72 \mathrm{~h}$ of incubation, $100 \mu \mathrm{l}$ of medium was removed from each well. Subsequently, $20 \mu \mathrm{l}$ of $0.5 \% \mathrm{w} / \mathrm{v}$ MTT (Sigma, USA), dissolved in phosphate buffered saline, was added to each well and allowed to incubate for a further $4 \mathrm{~h}$. After $4 \mathrm{~h}$ of incubation, $100 \mu \mathrm{l}$ of DMSO was added to each well to dissolve the formazan crystals. Absorbance values at $550 \mathrm{~nm}$ were measured with a microplate reader (Molecular Devices Inc., USA).

Statistical analysis GraphPad Prism 5 software (GraphPad Software Inc., San Diego, CA) was used for all the statistical analyses in this study. One-way ANOVA followed by Dunnet test were used to compared between extracts with positive control and $\mathrm{IC}_{50}$ was analyzed by using non-linier regression.

\section{Results and Discussion}

Total Phenolic and Flavonoid Contents

Phenolics are one group of larger secondary metabolites which are synthesized by plants and are utilized as UV, wounding and infection protectant in plants. Phenolics have been indicated to have several biological activities such as antioxidant, antimutagenic, anticarcinogenic, anti-inflammatory and antimicrobial activities in human [13]. 
As presented in Table 1, Mesocarp of P. macrocarpa fruit showed the highest phenolic content $(60.5 \pm 0.18 \mathrm{mg}$ GAE/g DW) followed by pericarp and seed with a value of $59.16 \pm 0.037$ and $47.70 \pm 1.036 \mathrm{mg} \mathrm{GAE} / \mathrm{g}$ DW respectively. The total flavonoid content of pericarp was found to be higher $(161.3 \pm 1.58 \mathrm{mg}$ rutin equivalent/g DW) than mesocarp and seed with the values of $131.74 \pm 1.665$ and $35.99 \pm 2.471 \mathrm{mg}$ rutin equivalent/g DW respectively.

From the results obtained, the total flavonoids contents was higher compared to the previous results which were reported by Rohyami [14] who reported the total flavonoids content from dry fruit (without seed) of P. macrocarpa (22.33 mg rutin equivalent/g DW) extracted by soxhlet using methanol as solvent.

\section{Antioxidant Assay for P. macrocarpa Extracts Total Antioxidant Activity Assay}

The FTC method was used to measure the peroxide level during the initial stage of lipid oxidation. Peroxides are formed during the linoleic acid oxidation, which react with $\mathrm{Fe}^{2+}$ to form $\mathrm{Fe}^{3+}$. The latter ions form a complex with $\mathrm{SCN}^{-}$ion and this complex has a maximum absorbance at $500 \mathrm{~nm}$ [15]. The individual activity of different parts of $P$. macrocarpa fruit extract by the FTC method (Figure 1) showed low absorbance values compared to negative control, which indicated high levels of antioxidant activity, as shown in Figure 2. The levels of antioxidant activity of the samples tested were lower compared to BHT (butyl hydroxyl toluene). Figure 2 shows the antioxidant activity of the tested samples measured by using TBA on the last day where the absorbance of negative control decreased. Results show a somewhat different pattern from that of the FTC method, where pericarp showed high antioxidant activity compared to mesocarp and seed. Pericarp extract showed no significant difference as compared to BHT as a standard antioxidant, which indicated the appreciable antioxidant activity of pericarp in retarding the linoleic acid oxidation. However the mesocarp and seed extract showed significant $(\mathrm{P}<0.01)$ lower activities as compared to the BHT. The differences in antioxidant activities observed here could be due to numerous factors, including the different mechanisms involved in the FTC and TBA methods, secondary metabolites in the sample, the antioxidant mechanisms exhibited by the compounds and possibly, due to the synergistic effects of different

\section{Table 1 Total phenolic and flavonoid contents of} different parts of P.macrocarpa fruit

\begin{tabular}{ccc}
\hline Sample & Total phenolic $^{\mathbf{a}}$ (mg/g DM) & Total flavonoid $^{\mathbf{b}}$ (mg/g DM) \\
\hline Pericarp & $59.2 \pm 0.04$ & $161.3 \pm 1.58$ \\
Mesocarp & $60.5 \pm 0.17$ & $131.7 \pm 1.66$ \\
Seed & $47.7 \pm 1.04$ & $35.9 \pm 2.47$ \\
\hline
\end{tabular}

${ }^{\mathrm{a}}$ Gallic acid equivalent. ${ }^{\mathrm{b}}$ Rutin equivalent. The analyses were done in three replications. compounds. However, the antioxidant activity of P. macrocarpa fruit might be attributed to the presence of flavonoid compounds presented in different part of the fruits. Hendra et al. [16] investigated the presence of flavonoid compound in different parts of $P$. macrocarpa fruit, and pericarp was found to contain several flavonoids such as kaempferol, myricetin, naringin, and rutin. Although the naringin and quercetin were found in mesocarp and quercetin in the seed extract.

\section{Antioxidant Activity of P. macrocarpa Fruit}

Antioxidant is defined as a substance which significantly delays or inhibits oxidation process. The antioxidant activity is measured indirectly by determining the inhibition rate of oxidation processes in the presence of an antioxidant [17]. DPPH, an organic stable radical in its crystalline form and in solution, is widely used to determine the antiradical activity of a given compound or extract. The antioxidant activity of a given compound or extract is also often associated with its radical-scavenging activity $[18,19]$. Figure 3 shows the free radical scavenging activity of pericarp, mesocarp, seed extracts of $P$. macrocarpa fruit and $\mathrm{BHT}$ at different concentrations. The results showed that pericarp gave the highest scavenging activity which was $71.97 \%$ while the lowest was seed extract which was $54.44 \%$ at concentration of $300 \mu \mathrm{g} / \mathrm{ml}$.

Furthermore, the ability of extracts to reduce iron (III) to iron (II) was determined and compared to butylated hydrotoluene (BHT) which are known to be strong reducing agents as shown on Figure 4. The result shows that the extracts could reduce iron in a dose dependent manner in pericarp, mesocarp and seed with values of $92.45 \%$, $78.78 \%, 66.40 \%$ respectively.

Figure 5 shows the NO scavenging activity of all the tested samples. All samples exhibited NO scavenging activity in a dose-dependent manner. The corresponding $\mathrm{IC}_{50}$ values for $\mathrm{NO}$ scavenging activity are presented in Table 2. All extracts showed $\mathrm{IC}_{50}$ values between 200-400 $\mu \mathrm{g} / \mathrm{ml}$ which indicated moderate $\mathrm{NO}$-scavenging activity. The NO scavenging values were categorized according to Tsai et al [20] and Oskoueian et al. [21]. The $\mathrm{IC}_{50}$ concentration (Table 2) showed significant differences in DPPH, FRAP and nitric oxide scavenging activity among the extracts obtained from different parts.

The antioxidant activity of $P$. macrocarpa fruit might be due to the presence of phenolic and flavonoid compounds since Hendra et al. [16] reported the presence of kaempferol, myricetin, naringin, quercetin, and rutin as the major flavonoids present in P. macrocarpa fruit. The correlation between flavonoids and their antioxidant activity might be due to the presence of a 3-hydroxyl group in the heterocyclic ring while additional hydroxyl or methoxyl groups at positions 3,5 and 7 of rings $\mathrm{A}$ and $\mathrm{C}$ seem to be less important [22]. This statement is in accordance with Amic et al. [23] who investigated 29 flavonoids for free 


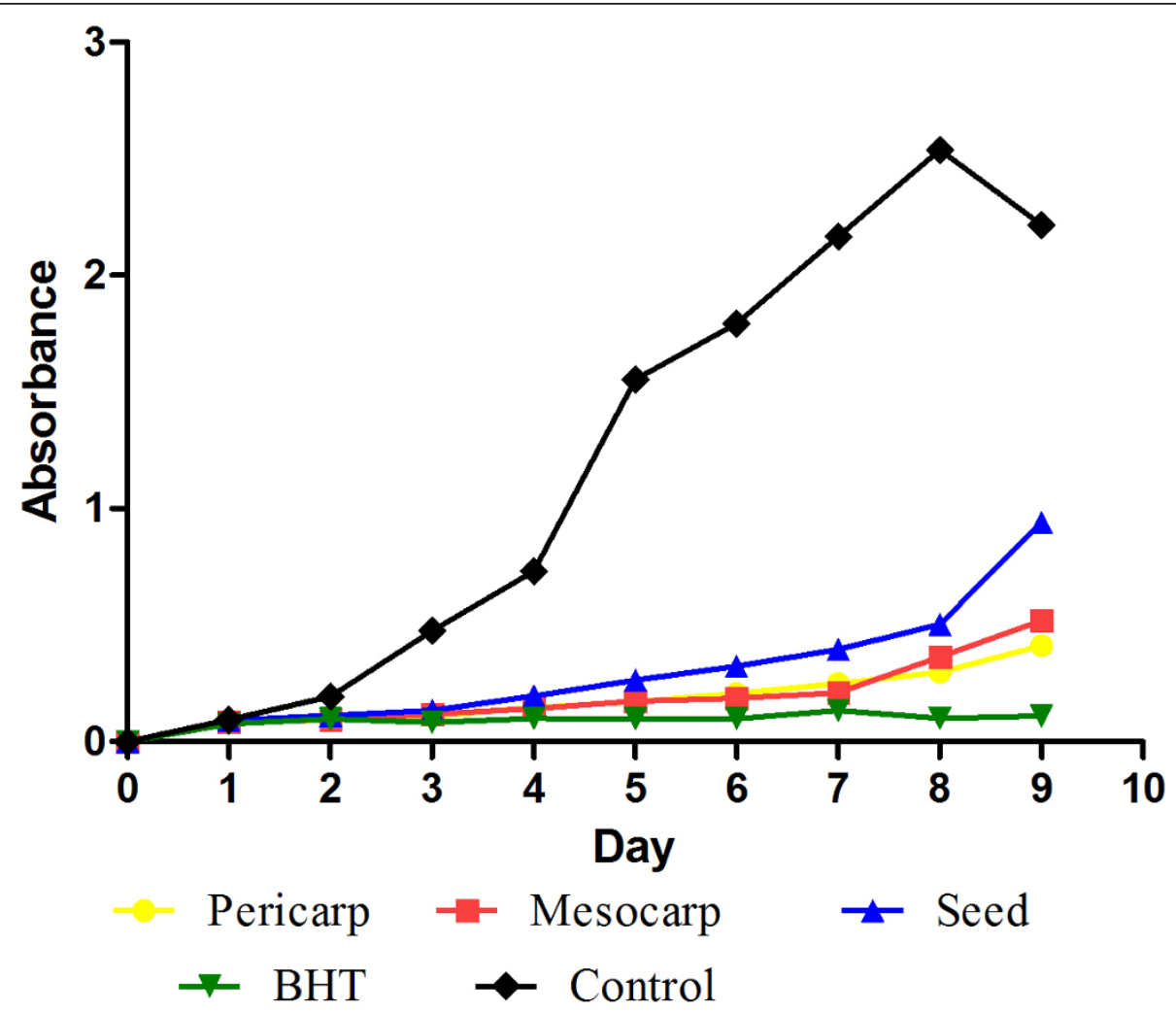

Figure 1 Absorbance values of samples at $300 \mu \mathrm{g} / \mathrm{ml}$ concentration using FTC method.

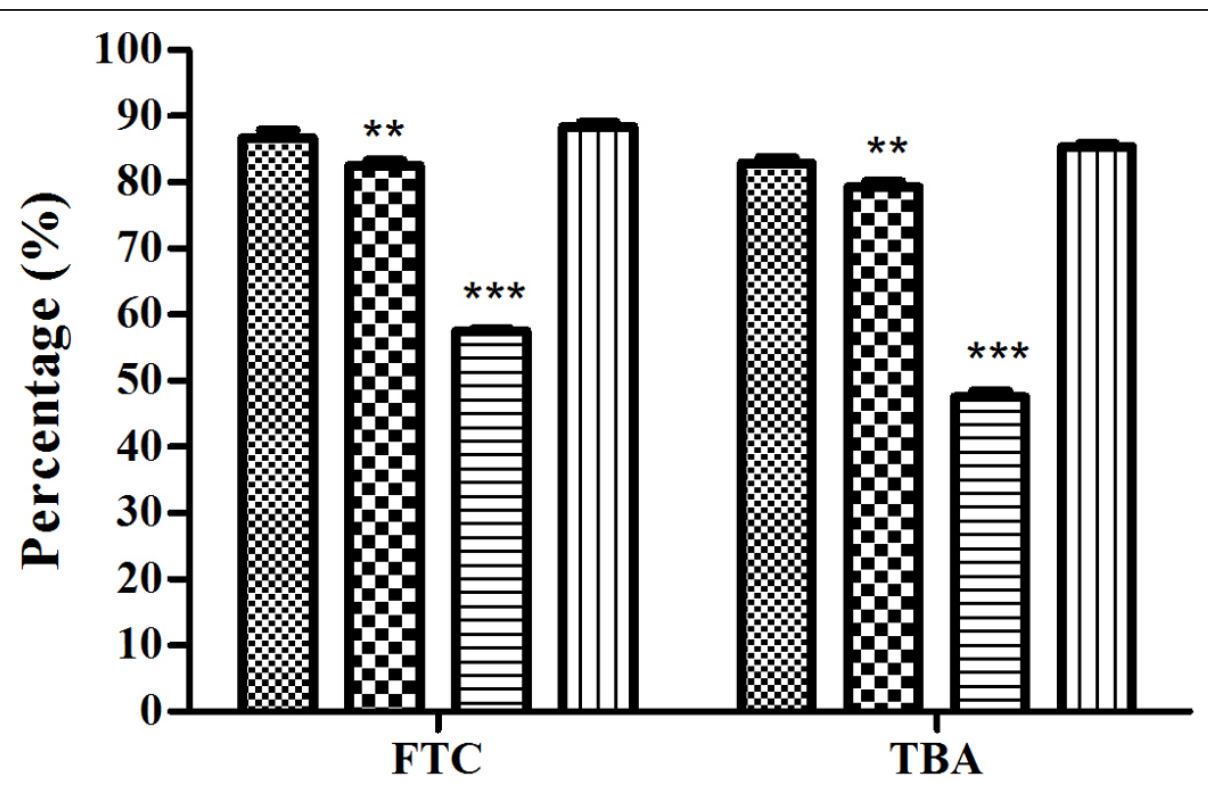

\$ Pericarp

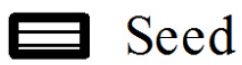

ax Mesocarp

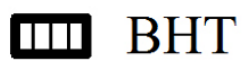

Figure 2 Total antioxidant activity assayed by the FTC and TBA methods on day $\mathbf{9}$. Each bar represents the mean \pm standard error in three independent experiments. ${ }^{* * P}<0.01$, ${ }^{* *} \mathrm{P}<0.001$ indicates significant difference as compared to BHT. 


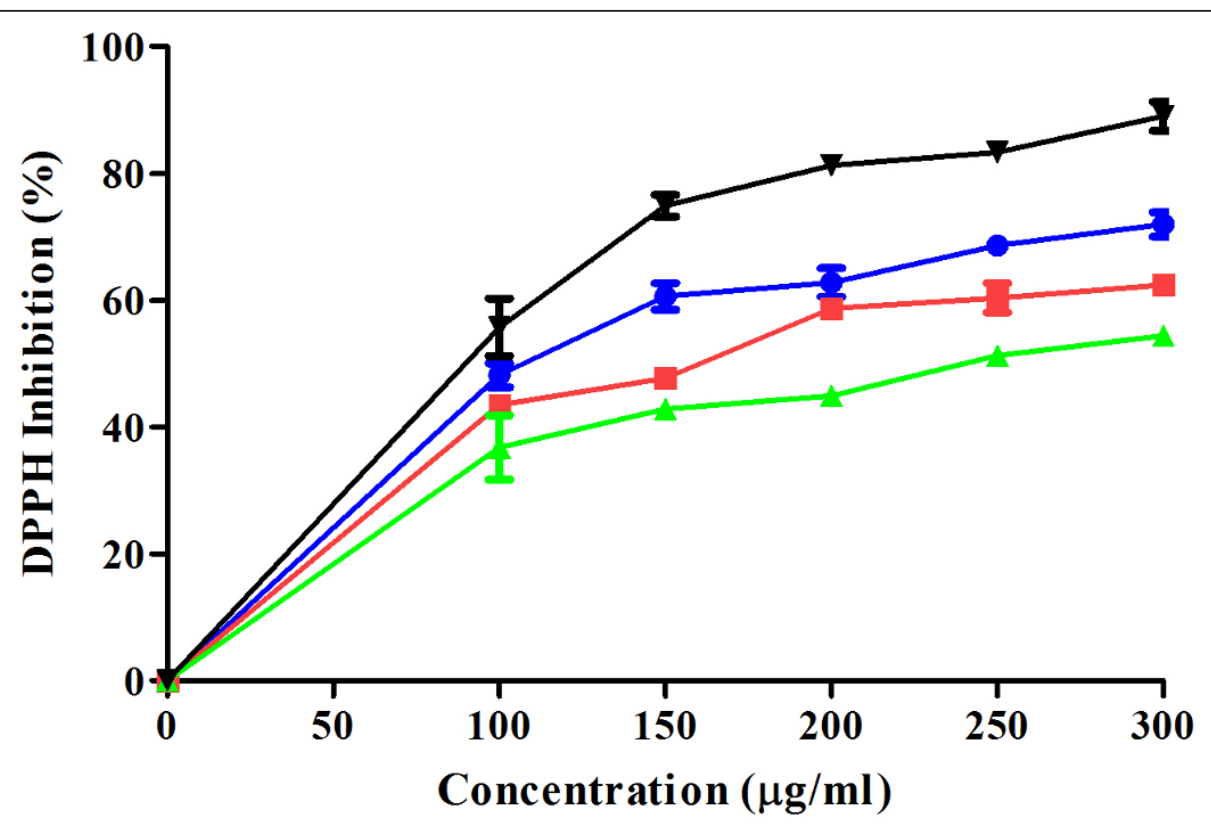

$\rightarrow$ Pericarp $\leftarrow$ Seed $\rightarrow$ Mesocarp $\rightarrow$ BHT

Figure 3 Free radical scavenging activity of extracts at different concentrations. Values are mean \pm S.E.M. of three experiments.

radical scavenging activity followed with analysis by using quatitative structure-activity relationship (QSAR) software. The results showed that the developed structure-antiradical activity indicated that highly active flavonoids possess a 3'4'-dihydroxy occupied B ring and/or 3-OH group.

\section{Anti-Inflammatory Activity}

During inflammation, the ultimate phase of a series of signaling events, macrophages induce the expression of pro-inflammatory genes such as inducible nitric oxide synthase (iNOS). This enzyme is up-regulated by

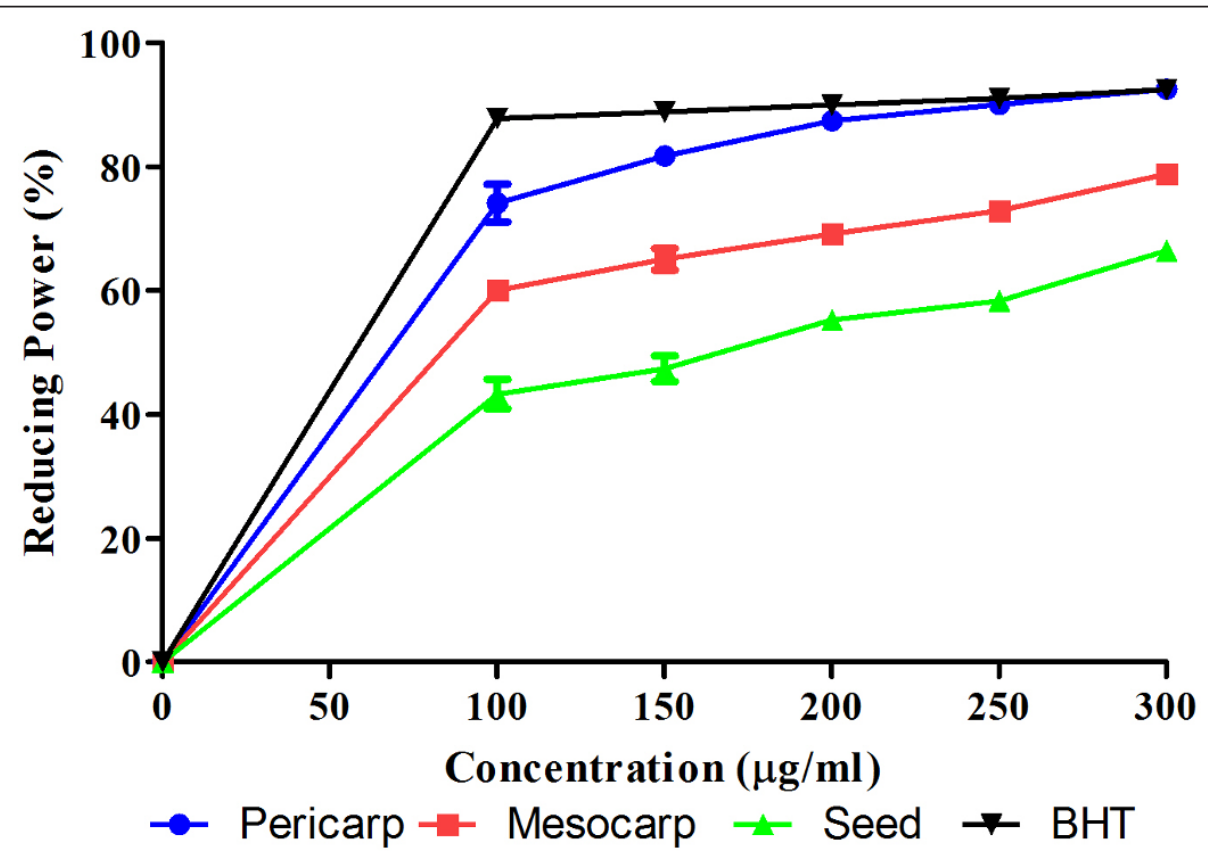

Figure 4 Reducing power activity of extracts at different concentrations. Values are mean \pm S.E.M. of three experiments. 


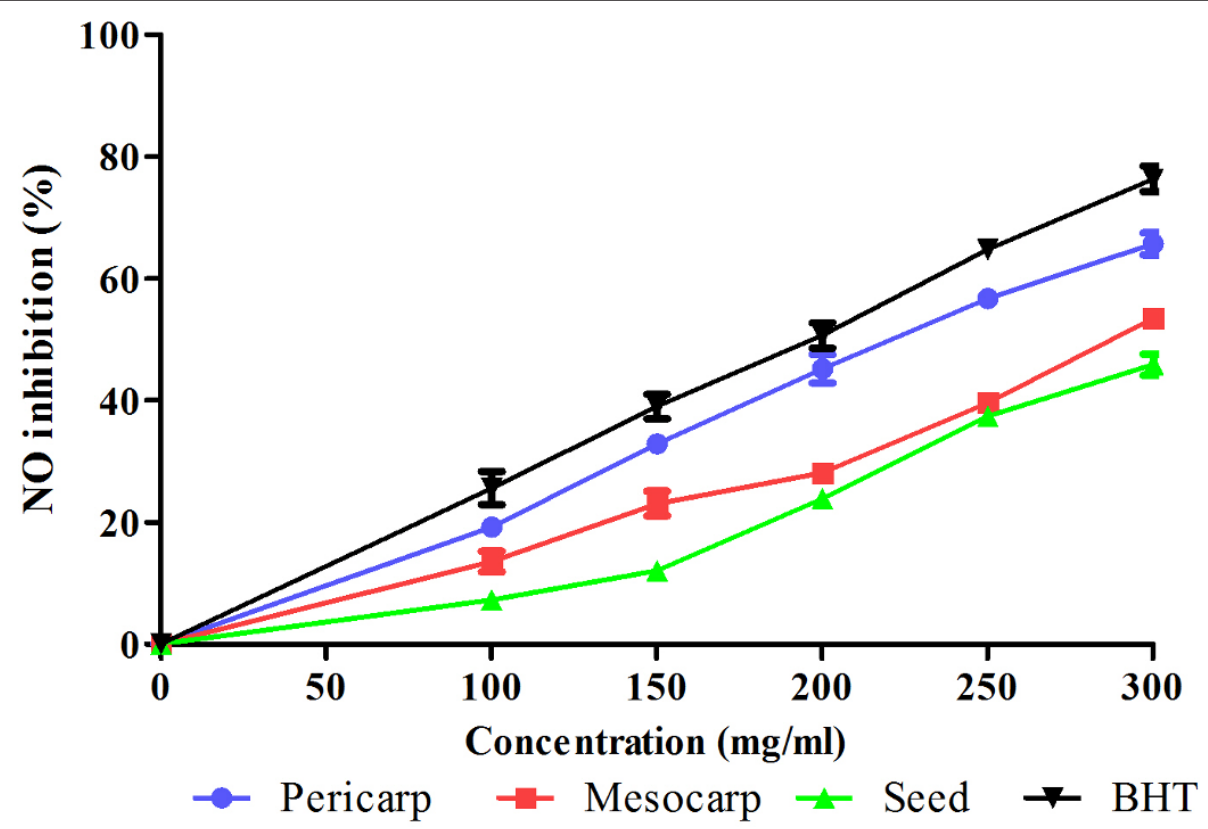

Figure 5 Nitric oxide (NO) scavenging activity of extracts at different concentrations. Values are mean \pm S.E.M. of three experiments.

secretion of pro-inflammatory cytokines, and produces NO from L-arginine. The regulation of NO production is therefore an important target for inflammatory disease $[21,24,25]$.

Anti-inflammatory activity was assessed using LPS/IFN$\gamma$ stimulated RAW 264.7 macrophages and NO production quantification using the Griess reagent. The cytotoxic effect of the extract was evaluated on macrophages using MTT to ensure that the anti-inflammatory activity was not due to cytotoxicity effect from the extract.

From Figure 6(a, c, e), all the extracts showed NO inhibitory effect in a dose-dependent manner. Mesocarp showed highest NO inhibition compared to pericarp and seed with values of $69.5 \pm 1.4 \%, 63.4 \pm 2.7 \%, 38.1 \pm 1.2 \%$ respectively. According to Kim et al. [26] classification, the percentage of NO inhibition from plant extract represent it's anti inflammatory potential therefore pericarp and mesocarp extract could be considered as moderate and seed extract as an week anti-inflammatory agent. As shown in Figure 6(b, d, f), pericarp and mesocarp showed

Table 2 The $I C_{50}$ values of extracts and standards on free radical, reducing power and nitric oxide scavenging activities

\begin{tabular}{cccc}
\hline Sample & DPPH & FRAP & NO Inhibition \\
\hline Pericarp & $142.4 \pm 1.14$ & $49.9 \pm 1.64$ & $212.3 \pm 1.33$ \\
Mesocarp & $230.3 \pm 1.75$ & $76.1 \pm 1.34$ & $261.5 \pm 1.83$ \\
Seed & $245.0 \pm 1.94$ & $150.2 \pm 1.28$ & $>300$ \\
BHT & $78.7 \pm 1.01$ & $24.8 \pm 1.32$ & $185.6 \pm 1.10$ \\
\hline
\end{tabular}

The analyses were done in three replications. percentage of cell viability more than $90 \%$ for all concentration except for seed extract. Seed extract with concentration more than $6.25 \mu \mathrm{g} / \mathrm{ml}$ showed percentage of cell viability dropped significantly.

The production of NO in positive control (L-NAME) was lower than all the extracts tested in this study. The lowest cell viability of the pericarp and mesocarp in RAW 264.7 cell line ranged from $90-95 \%$ while the seed extract showed $62.47 \%$ cell viability.

According to the results obtained from anti-inflammatory assay, $P$. macrocarpa extract appeared to be potent as anti-inflammatory agent and to the best of our knowledge this is the first report on anti inflammatory activity of $P$. macrocarpa fruit. The ability of $P$. macrocarpa fruit as anti-inflammatory agent might be due to the presence of phenolic and flavonoid compounds or other phytochemicals such as terpenoid compound which could play a role as anti-inflammatory agents. In vitro studies have confirmed that the flavonoids were able to inhibits nitric oxide production and the expression of iNOS but their strength depends on their structure or subclass of flavonoids [27]. Oskoueian et al [21] reported the role of phenolic compounds in antioxidant activity and their ability to act as free radical and NO scavengers, leading to the formation of phenoxyl radicals. Recently, Kazlowska et al. [28] suggested that the inhibition of iNOS in the RAW 264.7 cell is due to the NO suppressing action of flavonoid and phenolic compounds such as rutin and cathecol. Cytotoxic Activity

The results of cytotoxic activity of samples tested are presented in table 3 . From the results obtained, all the 

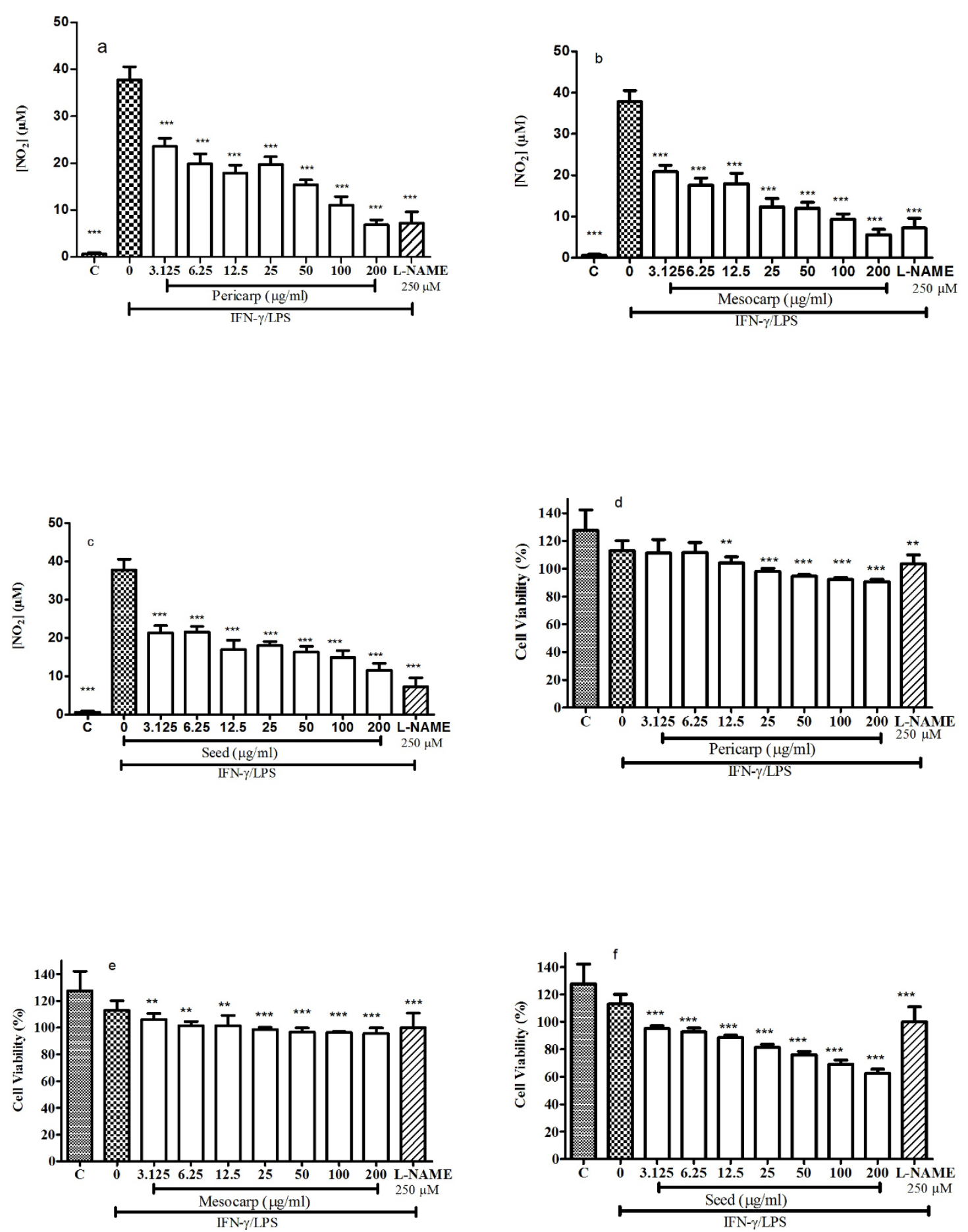

Figure 6 Nitric oxide (NO) production level (a, b, c) and RAW 264.7 cell viability (d, e, f) in the presence of pericarp, mesocarp, and seed. C; basal level of nitrite concentration without IFN- $/$ /LPS-treatment. All values are mean \pm S.E.M. of three different experiments. ${ }^{*} P<0.05$, ${ }^{* * P}<<0.01,{ }^{* * *} \mathrm{P}<0.001$ significantly different from the IFN- $\gamma /$ LPS-treated control group.

extracts could inhibit all cancer cells and normal human hepatocyte cells. Based on Boyd [29], a plant extract is usually regarded as interesting for in vitro cytotoxic activity when $\mathrm{IC}_{50}<100 \mu \mathrm{g} / \mathrm{ml}$. Based on this study, all the extracts showed interesting in vitro cytotoxic activity to all cancer cells with various $\mathrm{IC}_{50}$. Jonville et al [25] mentioned that the definition of promising activity was reserved for extracts with $\mathrm{IC}_{50}$ values of less than $50 \mu \mathrm{g} / \mathrm{ml}$ and that 
Table 3 The IC 50 values of extracts on HT-29, MCF-7, HeLa and Chang liver cell lines

\begin{tabular}{ccccc}
\hline Sample & \multicolumn{4}{c}{$\mathbf{I C}_{\mathbf{5 0}}$ Values $(\boldsymbol{\mu g} / \mathbf{m l})$} \\
\cline { 2 - 5 } & HT-29 & MCF-7 & HeLa & Chang Liver \\
\hline Pericarp & $70.1 \pm 1.94^{* * *}$ & $33.5 \pm 1.74^{* * *}$ & $40.8 \pm 2.01^{* * *}$ & $103.5 \pm 0.65^{* * *}$ \\
Mesocarp & $63.8 \pm 0.95^{* * *}$ & $26.2 \pm 2.01$ & $37.2 \pm 1.89^{* * *}$ & $110.7 \pm 0.71^{* * *}$ \\
Seed & $38.4 \pm 0.37$ & $25.5 \pm 1.37$ & $29.5 \pm 1.09^{* *}$ & $67.8 \pm 0.27^{* * *}$ \\
Tamoxifen & $37.5 \pm 0.84$ & $24.2 \pm 1.91$ & $28.8 \pm 1.94$ & $45.6 \pm 0.62$ \\
\hline
\end{tabular}

All values are mean \pm S.E.M. of three different experiments. ${ }^{* *} \mathrm{P}<<0.01$, ${ }^{* *} \mathrm{P}<0.001$ indicates significant difference as compared to tamoxifen.

further investigation regarding to isolation compounds and drug mechanisms were needed. From table 3, all the extracts show promising activity toward in vitro cytotoxic activity against MCF-7 and HeLa cell lines with $\mathrm{IC}_{50}$ between 25.5 - $40.8 \mu \mathrm{g} / \mathrm{ml}$. However, when applied to HT29 cell line, only seed extract showed promising in vitro cytotoxic activity.

Furthermore, Tamoxifen as positive control showed the lowest $\mathrm{IC}_{50}$ value as compared to other extracts. From table 3, there were no significant differences of cytotoxic activity between tamoxifen and seed for HT-29 and MCF7 cell lines. When tamoxifen was compared to pericarp and mesocarp, pericarp showed significantdifferences of cytotoxic activity for all cancer cells and mesocarp showed no significant difference with tamoxifen activity only for MCF-7 cell lines.

Since it is known that different cell lines might exhibit different sensitivities while treated with different plant extracts therefore the use of more than one cell line seems necessary for the comprehensive plant extract anti cancer activity screening. Cell type cytotoxic specificity of plant extracts is likely to be due to the presence of different classes of compounds in the extract [30].

Phaleria macrocarpa potency as an anticancer agent has been known empirically for generations, and its stem, fruit, seed or leaf boiled water extract have been used by people in Indonesia [31]. Faried et al. [32] have isolated gallic acid from fruits of $P$. macrocarpa and shown that it selectively induces cancer cell death in various cancer cells, such as human esophageal cancer (TE-2), gastric cancer (MKN-28), colon cancer (HT-29), breast cancer (MCF-7), cervix cancer (CaSki), and malignant brain tumor (CGNH-89 and CGNH-PM). The results demonstrated a significant inhibition of cell proliferation in a series of cancer cells. The cytotoxic activity results presented in this report (Table 3) are in agreement with Faried et al. [32] although further investigations on compounds responsible for cytotoxic effects in this fruit are required.

\section{Conclusions}

Pericarp and mesocarp from $P$. macrocarpa fruit show good antioxidant and anti-inflammatory activities. These activities might be due to the presence of phenolic and flavonoid compounds with various appreciable amounts.
The cytotoxicity activity indicated that all parts of fruit showed variable results and that the seed is a potential anticancer agent.

\section{Acknowledgements}

The author would like to thank the Faculty of Biotechnology and Biomolecular Sciences, Universiti Putra Malaysia for the laboratory facilities and Faculty of Mathematic and Natural Sciences, University of Riau for providing the samples.

\section{Author details}

1Department of Biochemistry, Faculty of Biotechnology and Biomolecular Sciences, Universiti Putra Malaysia (UPM), 43400 UPM Serdang, Selangor, Malaysia. ${ }^{2}$ Department of Chemistry, Faculty of Mathematic and Natural Sciences, University of Riau, Pekanbaru, Riau, Indonesia. ${ }^{3}$ Department of Microbiology, Faculty of Biotechnology and Biomolecular Sciences, Universiti Putra Malaysia (UPM), 43400 UPM Serdang, Selangor, Malaysia. ${ }^{4}$ Department of Chemistry, Faculty of Sciences, Universiti Putra Malaysia (UPM), 43400 UPM Serdang, Selangor, Malaysia. ${ }^{5}$ Agriculture Biotechnology Research Institute of Iran (ABRII)-East and North-East Branch, P.O.Box 91735/844, Mashhad, Iran.

\section{Authors' contributions}

$\mathrm{RH}$ conducted antioxidant, anti-inflammatory assay, analyze and interpretation of data, and drafted the manuscript. SA was responsible for conception and design, drafted the manuscript and revised it critically for important intellectual content. EO conducted cytotoxicity assay, analyze and interpretation of data, and drafted the manuscript. AS and YS were revised it critically for important intellectual content. All authors read and approved the final manuscript.

\section{Competing interests}

The authors declare that they have no competing interests.

Received: 14 July 2011 Accepted: 9 November 2011

Published: 9 November 2011

\section{References}

1. Balick M, Cox P: Plants, people, and culture: the science of ethnobotany Scientific American Library New York; 1996.

2. Sher A: Antimicrobial activity of natural products from medicinal plants. Gomal Journal of Medical Sciences 2009, 7:72

3. Kusuma IW, Kuspradini H, Arung ET, Aryani F, Min YH, Kim JS, Kim Y: Biological Activity and Phytochemical Analysis of Three Indonesian Medicinal Plants, Murraya koenigii, Syzygium polyanthum and Zingiber purpurea. Journal of Acupuncture and Meridian Studies 2011, 4:75-79.

4. Backer C, van den Brink R: Flora of Java (Spermatophytes Only), vol. II Noordhoff, Groningen, the Netherlands; 1965.

5. Zhang $Y, X u X$, Liu H: Chemical constituents from Mahkota dewa. Journal of Asian natural products research 2006, 8:119-123.

6. Crozier A, Jensen E, Lean MEJ, McDonald MS: Quantitative analysis of flavonoids by reversed-phase high-performance liquid chromatography. Journal of Chromatography A 1997, 761:315-321.

7. Ismail HI, Chan KW, Mariod AA, Ismail M: Phenolic content and antioxidant activity of cantaloupe (cucumis melo) methanolic extracts. Food Chemistry 2010, 119:643-647. 
8. Gulcin I: Antioxidant properties of resveratrol: A structure-activity insight. Innovative Food Science \& Emerging Technologies 2010, 11:210-218.

9. Yen $\mathrm{G}$, Chen $\mathrm{H}$ : Antioxidant activity of various tea extracts in relation to their antimutagenicity. Journal of Agricultural and Food Chemistry 1995, 43:27-32.

10. Tsai P-J, Tsai T-H, Yu C-H, Ho S-C: Comparison of NO-scavenging and NOsuppressing activities of different herbal teas with those of green tea. Food Chemistry 2007, 103:181-187.

11. Ahmad R, Ali AM, Israf DA, Ismail NH, Shaari K, Lajis NH: Antioxidant, radical-scavenging, anti-inflammatory, cytotoxic and antibacterial activities of methanolic extracts of some Hedyotis species. Life Sciences 2005, 76:1953-1964.

12. Mosmann T: Rapid colorimetric assay for cellular growth and survival: application to proliferation and cytotoxicity assays. Journal of immunological methods 1983, 65:55-63.

13. Falleh H, Ksouri R, Chaieb K, Karray-Bouraoui N, Trabelsi N, Boulaaba M, Abdelly C: Phenolic composition of Cynara cardunculus L. organs, and their biological activities. Comptes Rendus Biologies 2008, 331:372-379.

14. Rohyami Y: Penentuan Kandungan Flavonoid dari Ekstrak Metanol Daging Buah Mahkota Dewa (Phaleria macrocarpa Scheff Boerl). Jurnal Logika 2009, 5.

15. Liu Q, Yao H: Antioxidant activities of barley seeds extracts. Food Chemistry 2007, 102:732-737.

16. Hendra R, Ahmad S, Sukari A, Shukor MY, Oskoueian E: Flavonoid Analyses and Antimicrobial Activity of Various Parts of Phaleria macrocarpa (Scheff.) Boerl Fruit. International Journal of Molecular Sciences 2011, 12:3422-3431.

17. Antolovich M, Prenzler P, Patsalides E, McDonald S, Robards K: Methods for testing antioxidant activity. The Analyst 2002, 127:183-198.

18. Karimi E, Oskoueian E, Hendra R, Jaafar HZE: Evaluation of Crocus sativus L. stigma phenolic and flavonoid compounds and its antioxidant activity. Molecules 2010, 15:6244-6256.

19. Diouf PN, Stevanovic T, Cloutier A: Study on chemical composition, antioxidant and anti-inflammatory activities of hot water extract from Picea mariana bark and its proanthocyanidin-rich fractions. Food Chemistry 2009, 113:897-902.

20. Tsai PJ, Tsai TH, Yu CH, Ho SC: Comparison of NO-scavenging and NOsuppressing activities of different herbal teas with those of green tea. Food Chemistry 2007, 103:181-187.

21. Oskoueian E, Abdullah N, Saad WZ, Omar AR, Ahmad S, Kuan WB, Zolkifli NA, Hendra R, Ho YW: Antioxidant, anti-inflammatory and anticancer activities of methanolic extracts from Jatropha curcas Linn. 2011.

22. Pietta P: Flavonoids as antioxidants. J Nat Prod 2000, 63:1035-1042

23. Amic D, Davidovic-Amic D, Beslo D, Trinajstic N: Structure-radical scavenging activity relationships of flavonoids. Croatica chemica acta 2003, 76:55-61

24. Guzik T, Korbut R, Adamek-Guzik T: Nitric oxide and superoxide in inflammation. Journal of physiology and pharmacology 2003, 54:469-487.

25. Jonville $M$, Kodja $H$, Strasberg D, Pichette A, Ollivier E, Frédérich $M$, Angenot L, Legault J: Antiplasmodial, anti-inflammatory and cytotoxic activities of various plant extracts from the Mascarene Archipelago. Journal of ethnopharmacology 2010

26. Kim O, Murakami A, Nakamura Y, Ohigashi H: Screening of edible Japanese plants for nitric oxide generation inhibitory activities in RAW 264.7 cells. Cancer Letters 1998, 125:199-207.

27. González-Gallego J, Sánchez-Campos S, Tunon M: Anti-inflammatory properties of dietary flavonoids. Nutrición Hospitalaria 2007, 22:287-293.

28. Kazlowska K, Hsu T, Hou C, Yang W, Tsai G: Anti-inflammatory properties of phenolic compounds and crude extract from Porphyra dentata. Journal of ethnopharmacology 2010, 128:123-130

29. Boyd MR: The NCl in vitro anticancer drug discovery screen: concept, implementation, and operation. In Anticancer Drug Development Guide: Preclinical Screening, Clinical Trials and Approval. Edited by: Teicher BA, Andrews PA. Totowa, NJ: Humana Press; 1995:23-41.

30. Kamuhabwa A, Nshimo C, de Witte P: Cytotoxicity of some medicinal plant extracts used in Tanzanian traditional medicine. Journal of ethnopharmacology 2000, 70:143-149.

31. Harmanto N: Mahkota Dewa: Obat Pusaka Para Dewa. 1 edition. Jakarta: PT. Agromedia Pustaka; 2003.
32. Faried A, Kurnia D, Faried L, Usman N, Miyazaki T, Kato H, Kuwano H: Anticancer effects of gallic acid isolated from Indonesian herbal medicine, Phaleria macrocarpa (Scheff.) Boerl, on human cancer cell lines. International journal of oncology 2007, 30:605.

\section{Pre-publication history}

The pre-publication history for this paper can be accessed here: http://www.biomedcentral.com/1472-6882/11/110/prepub

doi:10.1186/1472-6882-11-110

Cite this article as: Hendra et al:: Antioxidant, Anti-inflammatory and Cytotoxicity of Phaleria macrocarpa (Boerl.) Scheff Fruit. BMC

Complementary and Alternative Medicine 2011 11:110.

\section{Submit your next manuscript to BioMed Central and take full advantage of:}

- Convenient online submission

- Thorough peer review

- No space constraints or color figure charges

- Immediate publication on acceptance

- Inclusion in PubMed, CAS, Scopus and Google Scholar

- Research which is freely available for redistribution

Submit your manuscript at www.biomedcentral.com/submit
C Biomed Central 